Authors: Julia Bennett, Manchester Metropolitan University, Interdisciplinary Studies, Crewe Campus, Crewe Green Road, Crewe CW1 5DU

\title{
j.bennett@mmu.ac.uk
}

Research Associate

Research Interests: Race; Community; Belonging; Place

Geraldine Lee-Treweek, Manchester Metropolitan University, Interdisciplinary Studies, Crewe Campus, Crewe Green Road, Crewe CW1 5DU

g.leetreweek@mmu.ac.uk

Principal Lecturer

Research Interests: Race; Migration; Community; Health

\section{Doing Race: how secondary school pupils in mainly white schools construct "race"}

\begin{abstract}
This paper examines how 'race' impacts upon the lives of young people who attend high schools, in a mainly white British area of the UK. 'Schools Stand up 2 Racism' (SSu2R), a Big Lottery research project, brought together a community partner the Cheshire, Halton and Warrington Race and Equality Centre (CHAWREC) and a team from Manchester Metropolitan University to investigate racism in High Schools. In an area where the population is over $93 \%$ 'white British', the sense that 'there's nothing to be racist about in this school' (year 8 pupil) was found to be common.

Through the three year SSu2R study, which used questionnaires, semi-structured interviews with teaching staff, focus groups with pupils and ethnodramas, a particular way of 'doing race' in Cheshire high schools emerged. The silent advocacy of a 'colour-blind' approach is promulgated through the popular rhetoric of 'everyone is unique' and 'we should treat everyone the same'. Moreover, the study found that whilst the media and parents are influential in shaping young people's understandings of race, it is a subject tackled only tangentially through the school curriculum. The paper shows how forms of everyday racism are endemic and yet largely unnoticed within these schools.
\end{abstract}

\section{Introduction}

This paper reports on findings from a three-year project into racism in a predominately white, semi-rural area of the North West of England (Cheshire) and in particular focus group data with secondary school pupils. Research into racism in mainly white schools has been carried out since the 1980s (Gaine, 1987; Troyna, 1993) but that does not, unfortunately, make the recent study of racism in schools in Cheshire, reported here, redundant. Twentyfive years on the issues raised by Chris Gaine in his first book are still relevant: learning 
about 'other' cultures is seen to promote tolerance; trainee teachers do not need much training on race and anti-racism and where there are few black and minority ethnic pupils racism is not a problem (Gaine, 1987). Troyna and Williams (1986) found education policies in the 1970s and 1980s were designed to manage the problems caused by the presence of black students. Multi-cultural education, they argued, did nothing to address the problems ethnic minorities faced from living in a racist society. These attitudes were also uncovered during our research, although multi-cultural education has been largely replaced by a focus on 'diversity' which includes anti-homophobic education, further diluting the anti-racist message The apparent insignificance of the problem means that one cannot simply define the issues and (attempt to) address them, but there is a need to look deeper into the process of embedding of these tropes into the culture of education in mainly white areas of the UK (that is, the majority of the country).

Research into racism in schools and educational tools to tackle racism often focus on the reports produced as outcomes of tragic crimes such as the murders of Stephen Lawrence in a street in south east London in 1993 (the Macpherson report) and Ahmed Iqbal Ullah in a school playground in Manchester in 1986 (the Burnage report). Whilst these reports are, of course, important in highlighting the potentially appalling outcomes of racist bullying, for many teachers in schools with a minority ethnic population of only $4 \%$, or less, their relevance is difficult to grasp. Due to a lack of training, teachers often equate racism with deliberate verbal or physical abuse. Many teachers do not recognise that racism extends into mundane issues such as uniform or dress codes, or behaviour towards pupils for whom English is an additional language. Many teachers feel pupils' personal identities should be subsumed beneath their identity as a pupil of the school, an attitude exemplified in 'not noticing what colour people are' (Soyei, n.d. p17). That this is a common stance was shown recently in the television series 'Educating Yorkshire' where Mr Mitchell, the headteacher of Thornhill academy stated to camera that:

As far as we're concerned within this school building the kids that are here belong to Thornhill Academy, they're not white, they're not Asian, they're not Muslim, they're not Christian, they're not atheist. None of those things apply here. We're all the same. It's something I feel extremely passionate about.'

(Educating Yorkshire, 2013)

Although race and ethnicity are only one facet of identity (Hall, 1996) they are, nevertheless, fundamental and embodied characteristics and cannot, therefore, be left at the door (Sandel, 1997). As Harries (2012) argues, spaces are themselves raced and here (in Cheshire) the school is clearly a white space.

Iissues such as these became apparent early on in this project which shifted the focus from incidents of racism towards gaining an understanding of the practices of racism. As Gillborn (2005) argues, racism is not simply something done by some white people as a deliberate expression of a particular set of beliefs; rather racism is the outcome of the social practices of all white people. To be white is not a performance of a particular kind of identity but a deeply ingrained way of being-in-the-world; it is a learned ideology or hegemony that places 
white people and white perspectives in the 'presumptive and residual category' (Benn \& Gaus, 1983, p6) that is the default, the norm, making the other, here all non-white British ethnicities, the deviant category. The schools in our research were 'predominantly white institutions' (Gusa, 2009) where non-whites must assimilate in order to achieve academic success (Hage, 1998; Harries, 2012). It is only by recognising whiteness as embedded in the structures of power within British society that 'institutional racism' can be recognised and tackled (Gillborn, 2008). In order to address the everyday racism that this study found perpetuated by white students in predominantly white schools, 'white' must be recognised as a racial descriptor too.

So the question that this research needed to address was 'how do white British people "do race"?' That is, how do these young people act white (Alexander, 1996). As Troyna (1993) has shown, a detached, 'objective' understanding of racism is impossible. Bearing in mind that '" $r$ r]ace" is a sensitive issue for white people to talk about. It is a modern taboo.' (Byrne, 2006, p. 72), we need to find a way of normalising talk about racism in order for teachers to feel comfortable in educating and addressing issues with pupils and in asking for more information and training for themselves. Although it should be borne in mind that in refusing to address race, white people may also be refusing to acknowledge, and rescind, the power their whiteness affords them (Mazzei, 2011). However, the key point we are making here about the 'whiteness' of this project about race is that it is white racism that was being examined, not the Black and minority ethnic (BME) people [1] who sometimes seem to be seen to 'cause' racism by their presence (Troyna \& Williams, 1986). In an area where the population is over $93 \%$ 'white British', the sense that 'there's nothing to be racist about in this school' (year 8 pupil) was found to be common.

\section{Critical Whiteness}

In the schools in this study, which were chosen in order to be representative of the High schools in the Cheshire sub-region, the vast majority of teachers and students are white British. It became clear during the research that this overwhelming norm of white Britishness, combined with a 'white blindness' (Gusa, 2009), was affecting the discourses of race and racism uncovered through interviews with teachers and focus groups with pupils (Hartigan, 1997). This is not to essentialise either whiteness or Britishness: racial groupings are not fixed categories but vary over time and combine in a variety of ways. Recent East European migrants are the largest 'white other' category in the geographical area of this research and stand outwith the 'norm' of white Britishness within these schools and some of these students told us that they have experienced racist comments. There are therefore limits and contingencies to any discussions of what is referred to as 'race', but it is possible, and indeed necessary, to use broad-brush categorisations to discuss understandings of racism in the limited space available here. We are therefore using 'white British' to describe the majority and Black and minority ethnic (BME) to describe all 'other' categories (including 'white other').

Whiteness is often overlooked as a racial category (Gillborn, 2005) with white (Christian) culture understood as the 'civilized norm', in Britain, whilst some other countries, and 
religions, are seen as 'behind' in terms of development. Where the white majority is as large as it is in the areas covered by this research, it is hard to see whiteness as a privilege, just as in an all boys' school the pre-eminence of males in society as a whole would not be recognised. Identities are always constructed in relation to an Other (Hall, 1996, p. 4); where the Other does not exist, an identity as 'White' cannot be constructed (Benn \& Gauss, 1983 , p. 6). Not only is one pole the 'norm', it is also meaningless without the other (Frazer and Lacey, 1993, p169). 'White' then does not exist as a racial category in the spaces examined in this research. Although there has been academic research into what it means to be white for over twenty years (Byrne, 2005; Dyer, 1997; Frankenberg, 1993; Gillborn, 2005; Hage, 1998; Harries, 2012; Hartigan, 1997; Nayak, 1997; Nayak, 1999), much of this has yet to penetrate mainstream British consciousness where to be white is the overriding norm. It is therefore possibly unreasonable to expect teachers to understand their own whiteness and the privilege this inevitably confers on them (Flynn, et al, 2009).

The predominance of White British identities in these schools amongst students and, to an even greater extent, teachers, precludes an understanding that identities are multiple, fluid and non-essentialist (Hall,1996). The teachers' focus in attending to the needs of BME students is, at different times, either an assimilationist or a 'colour blind' approach(Educating Yorkshire, 2013); although this is also interspersed with the convenient reification of ethnic identities when 'diversity' is on the teaching agenda. What is needed is a deconstruction of 'race' (including White British) as a singular identity category (Hall, 1996, p. 1) and to see race/ethnicity as merely one aspect of identity, which will become more or less dominant in different times, places and circumstances (Harries, 2012). But in the spaces of these schools the small number of BME students means that their sheer Otherness can engulf and make invisible additional sides of their identities. All of us negotiate our identities within specific social contexts to some extent, but some have more power than others to choose what those identities should be. This power is not absolute but varies in different circumstances (Harries, 2012). However, some identities give a person more power than others (Hage, 1998).

Schools are perhaps particularly constraining places in which to explore identity creation as 'the production of self as an object in the world' (Hall, 1996, p. 13). Schools can be seen to have aspects of 'total institutions' (Goffman,1961) with rules governing both overt 'classroom' behaviour and what can be called 'playground' identities. These are equally forceful normative subjectifications, that do not allow much 'play' in the selves that are produced there. Each of these spaces has its own rules of behaviour which, whilst apparently quite different, are, in fact, all derived from those of wider society with similar concepts of rationality and 'moral order' (Crossley, 1995, p. 139). We can understand these interactions as taking place between 'actor[s] qua embodied actor[s]' (Crossley, 1995, p. 138 ) in a particular milieu or social place, but where visible minorities [2] are present, their identity as Other may permeate all normative interactions. The way that racism plays out, the distribution of power between the various participants in the interactions, differs according to both the setting and who is present (Crossley, 1995, p. 136), but where those present are mostly white then 'acting white' will be the mode du jour that may well be taken up by some non-white students too (Nayak, 1997, p. 76). 
Different 'levels' of racism are present in these differently policed settings within schools. In common with Nayak's (1999) research in the North East of England, the study also revealed that 'students were keen to make a careful distinction between racism as a discourse of power available to them through regimes of representation (in language, speech, metaphors and imagery); and racism as a "chosen" subject position that was explicitly ideological and practised in daily, vehement exchanges' (p. 237). The term 'racist' has itself become a derogatory one amongst school children, although uses of words such as 'Paki' and 'nigger' are not seen as racist when not directed at an individual and what Nayak referred to as 'unevenness of racism' (p. 237) has developed into what is now accepted as 'banter', or 'joking around' (Raby 2004). Although as sociologists we can refer to the use of 'nigger' as a 'discourse of power' this is not a conscious use of white power (although use of white power is very rarely conscious). We found that BME students also claim to excuse it as a lack of understanding on behalf of the white British students, rather than 'racism' which is considered a deliberate act. However, this may make the impact on the BME students more difficult to address as they often feel unable to challenge this discourse of muted racist power for fear of conforming to some particular image of how BME students should behave (Nayak, p. 73). Racism is, despite the best efforts of MacPherson and others, still seen by teachers as individual actions rather than embedded into the structures of power and policy (Gillborn, 2005).

\section{Not talking about it: Bourdieu, discourse and doxa}

The power of discourse has limits as an explanatory tool for the way in which many BME students acquiesce with racist 'banter'. Similar to the way in which a colour blind approach refuses to see racism and thus denies its existence, a refusal to name racism as racism denies its existence (Raby, 2004). 'Banter' and 'joking around' are particularly difficult to fight against as the power of humour can act to maintain a colour blind ideology (Sue \& Golash-Boza, 2013).

The inability of BME students to respond with feeling to white friends using terms such as 'nigger' can also be understood as doxa (Bourdieu, 1977). Doxa is the realm of the 'universe of the undiscussed' (p. 168), which, because it is beyond discourse, beyond words, is also beyond what can be thought and is therefore 'invisible' (Lundy, 2003, p. 462). Bourdieu describes doxa as 'that which is beyond question and which each agent tacitly accords by the mere fact of acting in accord with social convention' (1977, p. 169). There are two aspects of Bourdieu's concept of doxa that can be usefully deployed here: firstly, and more conventionally, BME students do not have the language (because it doesn't exist) to position themselves equally against a white heterodoxy. Benhabib (1992, p. 98) points out that '...any definition of a group's identity not in terms of its own constitutive experiences but in terms of its victimization by others reduces that group's subjectivity to the terms of the dominant discourse and does not allow for an appreciation of the way in which it may challenge that discourse'. These students negotiate whiteness every day and are, no doubt, 'highly adept, at desconstructing whiteness' (Nayak, 1997, p. 75), but this is a practice of whiteness without an associated discourse; because the very idea of whiteness as a racial 
category (at least in the social spaces examined here) is not a part of the definition of reality that we are working within (Bourdieu, 1977, p. 170). Secondly, white teachers have neither the language nor the understanding to educate white students about race, possibly because it is rarely covered in PGCE courses or in service training (Ajegbo, 2007, Pearce, 2012). This may be due to the perception of a colour-blind approach as being the most 'politically correct' attitude towards BME pupils: 'you shouldn't notice what colour they are' (Soyei, n.d.), whereby black and ethnic minority pupils become deracialised (Lundy, 2003) or 'white by proxy' (Jones, 1999, p. 45). In common with other research, such as that conducted by Cline et al, a team from the University of Luton writing for the DfES in 2002, we found that students adopt this approach, at least in the formal space of the classroom (Harries, 2012). Not actively addressing race or racism hides the perceived 'problem' of race behind a 'spiral of silence' (Noelle-Neumann, 1974). This could be, and is often formulated as, a fear of offending (Byrne, 2005; Harries, 2012; Mazzei, 2011). However it could also be, as Mazzei (2011, p. 660) says a 'recognition of their need to maintain privilege, identity and comfort'. Orthodox discourse acts to censor how we speak, and therefore think, about the world. This leaves BME students unable to fully articulate their experiences of the kind of everyday racism encountered in their mainly white schools (Benhabib, 1992; Bourdieu, 1977); Nayak, 1997). 'White blindness' (Gusa, 2009) is another aspect of 'colour blindness'. The overwhelming heterodoxy of whiteness and the orthodoxy that prevents race from being discussed openly, pushes race, racism and any idea that the world (here limited to that of secondary schools in Cheshire) could be other than it is outside the realm of discourse. Whiteness is equivalent to power as both 'what goes without saying' and 'what cannot be said' (Bourdieu, 1977, p. 170).

\section{Assimilation and tolerance}

For many of the schools in the SSu2R research, talking about race involves 'celebrating diversity' - that is, a multi-cultural approach. This approach has been criticised as hiding the real issue of equality behind a focus on managing the problems inherent in 'difference' (Troyna \& Williams, 1986). This is an individualistic approach that treats any deviation from the norm of white Britishness as 'difference' which can then become essentialized and 'hide' racism behind 'culture' (Berman \& Paradies, 2010, p. 220). Where difference is focussed on to the exclusion of all else, the complexity of identities may be lost (Hall, 1996). Equal but different, which smacks of US segregation laws, misses the power relations inherent in different ethnicities and cultures. Ghassan Hage (1998) points out that multiculturalism is based on a discourse of power, of 'us' tolerating 'them'. To tolerate requires both someone to do the tolerating and someone to be tolerated. Those who tolerate, also have the choice to refuse to tolerate; those being tolerated do not have a choice. Therefore, '[m]ulticultural tolerance ... is a strategy aimed at reproducing and disguising relationships of power in society' (Hage, 1998, p. 87). Racism is not, as the Edexcel GCSE specification in Religious Studies would have it, 'the belief that some races are superior to others' (Pearson Education Ltd, 2013, p. 106) and therefore a problem which can be eliminated through education about other different (but equal) cultures. Racism is the exercise of power, sometimes directly at an individual level, but more often through structures within society and the processes and mechanisms by which the established order is reproduced (Bourdieu, 1977, p. 
190). Unfortunately, racism is still often seen by teachers as individual actions, rather than embedded in the structures of power and policy (Gillborn, 2005).

The issue at stake here, amongst the largely white population of our research, is that those with power are unable (or refuse) to see the power they hold (Gillborn, 2005; Gusa, 2009; Hage, 1998). This is likely to be the case amongst our student population who will all have some feelings of powerlessness in a school setting. The combination of a politically correct colour-blindness, particular constructions of race within the curriculum, popular media culture and other external influences, and lack of regular contact with Black and Minority Ethnic people, creates a way of 'doing race' that sediments everyday racism within the educational context of these students. Through analysing the responses of students within the SSu2R research it has been possible to identify some of the pitfalls of particular aspects of the educational context and suggest ways to improve awareness of race amongst students.

\section{Methods: The Schools Stand Up 2 Racism project}

The 3 year Big Lottery funded project was looking at the extent and forms of racism in secondary schools in Cheshire, Halton and Warrington, largely white areas of the UK. The aims of the project were to improve the understanding of race amongst both teachers and pupils in order to reduce the racism experienced by the minority non-white-British population.

Much of the previous research into mainly white schools has been conducted through interviews and questionnaires with teachers. The project involved speaking to teachers to gain an overall picture of the schools' policies and ways of dealing with racism/anti-racism education but we were eager to include the perspectives of students within our research. To this end a questionnaire with year 8 (12 - 13 year olds) and year 11 (15 - 16 year olds) in five schools $(n=1300)$ was administered, and then focus groups were held in the same schools with the same year groups. Some of the typical issues and examples of incidents that were brought up in the focus groups were then taken and used to develop a series of 4 mini-ethnodramas. Third year drama students from Manchester Metropolitan University were used to present these to year 8 pupils at the five schools (as this was in the subsequent school year this was a different set of pupils). The ethnodramas were used as prompts to enable the students to talk about their experiences. These were mixed groups of white British and BME pupils. The final method used was based on small group work that the authors had undertaken previously with migrants and white communities (author and author, respectively). These last data collection tools are termed 'cluster groups' and involve inviting BME pupils to invite along close friends to discuss issues. In doing this is it is possible to provide a confident, safe (safer) environment for BME students to talk about race. Friends can also sometimes have interesting perspectives on how they perceive issues of race and racism in relation to their BME friend, and/or sometimes they themselves may be from BME backgrounds. Moreover, these interviews collect longer narratives of race than focus group settings, where there are numerous interjections and no time for full accounts. The data presented within this paper are drawn, predominately, from the focus groups and cluster interviews. 
The data were analysed using an iterative approach. As the data were collected over the course of eighteen months analysis took place on each set of data independently, initially. The analysis of, for example, the questionnaire data fed into the subjects explored in the initial student focus groups, which, in turn, led to the development of the ethnodramas (Kaptani \& Yuval-Davis, 2008). This cycle of progressive inductive and deductive verification allowed the various themes to emerge from the data (O'Leary, 2004). The initial research question was to identify the extent and nature of racism in Cheshire schools with the additional aim of assisting schools in dealing with this.

The research was carried out with a high degree of reflexivity by the researchers and an awareness that the ethnic make-up of the team will have influenced some aspects of the findings. As white researchers we have to understand that we also have a 'race' which affects how we see and understand the world and how those we are researching see us. Troyna (1993) has shown that, a detached, 'objective' understanding of racism is impossible. The researcher herself is always a part of the social and political relations that go to make up the research process. There are contradictory views on the benefits of ethnic matching in research and the possible influence of team ethnicity, when studying issues of race and racism (Gunaratnam 2000; Hoong Sin 2007). In researching mainly white schools, it could be an advantage for researchers to be white, as teachers and pupils are not immediately on their guard against saying something that might not be quite the right thing. Conversely, an ethnically white British team may have a silencing effect upon BME students, who may feel less able to be open about their experiences. During the initial stages of the research one of the researchers was British Asian, the others white British. For the final eight months of the project (when the ethnodramas and the cluster interviews were carried out) all the researchers were white British. The presence of the British Asian researcher may have stifled some discussion at some of the focus groups, although it is hard to quantify this. Overall we felt that as white researchers it was perhaps easier for the white students to express themselves; although conversely in the cluster interviews with BME students there may have been a more negative effect at times. - see Chadderton for more here

Overall we have found that where both teachers and pupils have very little contact with non-white British people, particular ways of constructing 'race' develop through the History, English and Religious Education curriculum, and these constructions are typically supported and reinforced by popular media culture and the opinions of parents.

\section{Playground language}

Schools are now being encouraged to ally racist bullying to other types of bullying, through the reporting of incidents, which encourages teachers to see them as 'the same' thing (this is related to the implementation of the 2010 Equalities Act and hate crimes). This is the kind of 'objective' and 'rational' standpoint Hage (1998) cites as stemming from a particular Eurocentric view of the world, which is itself racist. Racist bullying goes to the heart of a person's identity and attacks not only the individual but also their family and community. As other research has found racist bullying can lead to trouble around the young person's sense of identity and belonging (Cline et al, 2002, p. 51). 
The racist incidents which are noted as such by the largely white focus groups are most often about language. There is a perception that politically correct language is the antithesis of racism: saying the right thing is more important than thinking or doing anti-racism (Flynn, et al, 2009). At one school we visited pupils openly referred to the local sweet shop as 'the Paki shop' without understanding this as racist language.

Anna: I think, like, it's OK to call a shop like that a Paki shop but, like, you've got to be careful how you say it. Like, if you say it to someone who owns a shop it can be a bit offensive but if you're just saying it, like, as like the shop is, like, known it might be OK.

Interviewer: Ah right, OK.

Lydia: On [estate name] there is a shop what people call the Paki shop.

Interviewer: Oh is there? Is that near here?

Lydia: Yeah. And people, like, tend to call it a Paki shop because of the people that own it. Like, they're different to us and have got different colour skin and, like, if you say to, like, your friend 'I'm just going to the Paki shop' and someone else hears you and they don't really know you that well they might think that you're a bit racist to that shop, when the shop has a name, the newsagents, and you're calling it a different, Paki shop.

\section{Year 8 Ethnodrama focus group}

This illustrates the wider point that practices do not necessarily follow rules: the children using this term would certainly not consider themselves to be racist - they demonstrated that they understand there are certain rules that would define one as racist; but they do undertake racist practices as part of their un-considered everyday lives (Harries, 2012; Nayak, 1999). Although these young people have some understanding of what racism is, in terms of a definition of the word - that it is seeing some people, defined by their 'race' or ethnicity as inferior to others - they do not understand or question how racism is done:

Coz when people, most people in the school don't mean to be racist when people say stuff coz it's just, like, a joke.

Where one group has more power than another displays of power are 'normal, and do not require malice on the part of the perpetrator' (Frazer and Lacey, 1993, p89). The doing of racism is a culture that is created and re-created as part of an ongoing and dynamic process (Alexander, 1996, p. 18; Nayak, 1999; Raby, 2004).

\section{Year 11 Student}

Racism is constructed as an intentional act to hurt someone and jokes, not intended to cause harm, cannot therefore be racist. The idea that many comments are not really racist, not bullying, because not necessarily directed at an individual and are about stereotyping and generalising rather than treating people as individuals is a theme that came through strongly in both the student focus groups and the teacher interviews: 
Quite a few of the incidents we're dealing with at the moment, it's not racism per se, if that makes sense, it's the language that student might have said is clearly not their own, they're using something they might have heard at home and then making a generalised stereotype style comment rather than actually bullying someone.

\section{Teacher}

Racism within these schools is seen as a problem of the individual - the one who creates the racist incident or uses racist terminology - rather than located within the structure of society. When racism is located in the characteristics of individuals in this way racial prejudice can be seen as a 'misunderstanding' which multi-cultural or diversity education can correct. In individualising racist attitudes, those subjected to them are also blamed as individuals, hence the idea amongst many mainly white schools that racism is not a problem for them but is brought into the school if BME pupils arrive (Gaine, 1987) who then become somehow to blame for the racism the other pupils inflict on them (Nayak, 1997)

And there is, you know, I'm being completely honest, there is always that assumption that 'well if there are, there are not that many black children in school so it's not an issue' Teacher

Whiteness is the norm: even to be normally deviant (gay/lesbian, disabled) is to be white (Dyer, 1997, p. 12). Racism is deeply embedded in white culture, including the middle-class liberal rhetoric of not noticing colour as much as the more strident BNP type racism. These attitudes ignore the external societal structures that give rise to the 'everyday-ness' of many racist attitudes (Gillborn, 2005; Nayak, 1997). Indeed the overt racism of some groups is easier to combat than the everyday-ness of structural or institutional racism (Gillborn, 2005). Incidents of overt racism within schools can be seen as a symptom of underlying attitudes amongst some students, and sometimes staff, rather than as either a cause of racism or an isolated incident, as they often seem to be understood by the teachers interviewed (Asare, 2009).

A particular boy who I dealt with... he complained about somebody saying something to him and then...it came out that a number of his mates had said things to him but because they were his mates, he didn't take as much offense to them...So it has happened in the past but that had obviously gone unreported because, in his, his perception was 'Oh they're my mates and they're just messing around' and in a way it was sort of well you can't have it both ways, you can't sort of accuse one person of being racist towards you, when actually your mates are doing a similar thing and not accuse, you know what I mean?

\section{Teacher}

Racist incidents are not sui generis but are an indication of a culture of racism, which may be tacit, but is nonetheless present in the school and the community/society of which it is part. Although not framed as a specific question during these interviews, none of the respondents explicitly identified themselves as white. In common with white pupils in other research (Nayak, 1999, p. 33) there was no indication that any of the teacher respondents saw white identities as also being racial identities (Byrne, 2005; Dyer, 1997; Frankenberg, 1993; Gillborn, 2005; Gusa, 2009; Hage, 1998; Harries, 2012; Nayak, 1999). 'White 
blindness' cripples any wider understanding (Gusa, 2009). These structural (or institutional) aspects show themselves clearly in the way the curriculum addresses issues of race.

\section{Rewriting the curriculum: Pupils' (mis) understandings:}

From speaking to pupils at five schools in the Cheshire region we have found that the key areas of the curriculum where race is mentioned are History, Religious Education, Citizenship or PSE (personal \& social education which deals with relationships, sexual health, job applications and a variety of other things) and English Literature. The History curriculum seems to confuse as much as educate in that there is no overall understanding of how different aspects such as slavery, Rosa Parks, Malcolm X and apartheid fit together. Many students seemed to think that there had been 'progress' so that racism now is not as bad as it used to be when people had to sit on separate benches (Year 8 student). This seemed to coalesce into a narrative that suggested a teleological approach to race. Positioning racism as a part of history is another way of denying any involvement in it

There are misperceptions as to where these things happened as well as when so that American history becomes British history too.

Carla: Like you hear stories from, like, the 60s and stuff where they tried to keep, like, schools white and they, like, kept separate places from, like, black people to white people so, like, black people couldn't sit on a bench, like, separate from white people and stuff, but it doesn't happen that now. Like we're all, like, treated the same and stuff.

\section{Year 8 Focus Group}

Although this teaching does not deliberately promote the idea that black people should be seen as fundamentally different or inferior there is still a construction of an 'Other' who can now be brought into the fold of 'normal' whiteness (Gusa, 2009). History is always the recreation in the present of what (might have) happened in the past and it is therefore understood within the social context of the present and this is how the young people we spoke to interpret it. Teaching about the treatment of black people in the past, on other continents, does not automatically create an understanding of why Britain today is a multiethnic society.

Although prejudice and racism are on the RE curriculum there seems to be little open discussion of the issues.

Marshall: RE. So we do, we did, like, sections about how people react to other people of different ethnicities and stuff like that, so we did it then but other than that there's not much cause to talk about it.

\section{I: Mmm-hmmm. And what, did you have kind of quite a bit of a debate in} RE or not?

(Silence)

I: You just got taught? 
Marshall: Well yeah coz there's this, it's wrong isn't it, so there's not really much debating to be done.

Year 11 focus group

The sensitivity of the subject of race makes it impossible to discuss in these classrooms where the teachers do not have the confidence to address the issue (Gillborn, 1995, Pearce 2012). In Citizenship or PSE racist bullying is often covered under the bullying agenda, rather than being separated out as something that is different. Racism is not 'just' bullying: racism attacks whole groups of people (whether directed at one individual or not) and attacks fundamental aspects of identity.

English Literature is also a good opportunity for teaching about racism. There are many books written specifically for teenagers by popular authors such as Darren Shan and the children's laureate Malorie Blackman, but these authors were only mentioned by students on one or two occasions. Most of the reading about race was related to set GCSE texts from American literature such as 'To kill a Mockingbird' by Harper Lee and 'Of Mice and Men' by John Steinbeck, both of which make frequent use of 'nigger' as would have been the norm at the period and place in which each book is set. Where there are only one or two black students in the class and the teacher is unable to confront issues of race the reading of these texts can isolate the BME student and create tension between the black and white students:

Alistair: It's like, when we were in English, did you do To Kill a Mockingbird in English?

Simon: Yeah, that was a bit awkward.

Femi: Yeah, they were all looking at you like...

Alistair: Yeah, how awkward that makes us feel when they say the word nigger everyone looks at you...

Simon: They all go [makes whooshing sound].

Alistair: And they don't understand how it makes you feel. They're kinda looking at you as in 'That relates to you mate', you know what I mean? So you're there like, trying to just bury your head in the book like.

\section{BME Cluster Interview}

'Classroom' identities and rules prevent the other students from commenting on the use of 'nigger', a word with which they are familiar from popular music. However students admit to using this word in the playground and deny that it has any racist intent. These differences in context and use of language mirror Nayak's (1999, p. 237) findings between racism as a 'discourse of power' in the playground and 'a "chosen" subject position' in the book/classroom context. Whilst we did hear of some examples of racism, sometimes deliberate, within the classroom, the majority of incidents around racial difference seemed to happen in the unpoliced spaces of the school. This is perhaps 
unsurprising, but it might demonstrate a richer understanding of racial abuse than students were able to disucss with us. As Mezzai (2011) points out, silence can be powerful. In understanding race as 'off limits' in the classroom, as Marshall demonstrates above, white students are perhaps showing how they do understand the power of words such as 'nigger', whilst simultaneously denying any exercise of that power when they use the word 'as a joke'. White students are thus asserting their power against both the teachers, who seemed to be unaware of the extent of the use of these words in the playground, and at the same time, demonstrating their position of power vis à vis BME students. Cite Foucault here?

Overall there seems to be little incentive to address race and racism within the classroom. Teachers appeared to be uncomfortable talking about the subject and although students often said they would like more information many also indicated on feedback forms that they felt they knew a lot about racism already. Without some impetus, probably external, teachers are unlikely to add more difficult topics to their workload.

\section{Conclusion}

This research has found that there is little discussion of race in these schools. This leads to a group of young people growing up in a 'multi-ethnic' society and yet not fully a part of that multi-ethnicity. The vast majority of these young people, and their teachers, are not racist in the sense of it being a chosen subject position (Nayak, 1999), and yet many of their actions discriminate and reinforce the structural inequalities that BME people face. Being called a racist is stigmatizing; whilst 'nigger' is used by these young people in everyday speech, 'racist' is an unacceptable term that is moving into the realm of doxa (Bourdieu, 1977) and, almost, cannot be spoken.

Modern tropes around individualism and everyone being the same/unique do not help to counter the stigmatization of difference, whether this is based on race, ethnicity, religion or skin colour (Raby, 2004). In the UK white British is the norm and difference is, usually, 'tolerated' (Hage, 1998), implying a situating of power amongst those who do the tolerating. It is clear from this research that BME students are tolerated in the mainly white schools. A/l identities are fluid, intersectional, and complicated, perhaps particularly so for teenagers, but for many of the BME pupils their identities are shaped by attending mainly white schools. It is not necessary to treat everyone 'the same' or to believe that we can leave our histories and identities at the door in order to espouse equality. In fact, an equality based on stripping away the essential aspects of a person that go to make up their identity is a negative equality. The idea of an 'ethic of care' (Kymlicka, 2002, p398) appeals to concrete individuality taking personal history into account: this combines a form of reflective reasoning with a consideration of embodied individuality (Benhabib, 1992, p159). Such an approach allows for equality and individuality without sameness. Young people in these schools are largely unaware of their own constructions of race and racism. Their understandings of what racism is run counter to how they 'do race'. Their everyday speech and actions create a space where BME pupils are tolerated, but they, in turn have to endure a level of everyday racism (Hage, 1998). Despite racism being seen by students, as well as teachers, as unacceptable, practices of racism such as using racist language, are accepted. 
Joking around is not seen as racism and to call someone racist would be to insult them and is therefore seen to be unacceptable where the racism is not intentional.

In order to address the racism that this research has uncovered it will be necessary for schools to find a way to bring race back into the orthodox realm as something that is within schools' remit. Racism takes different forms and is not always overt or directly targeted towards minorities. Many of the young people who took part in this research participate in and perpetuate forms of racism unknowingly as part of their unacknowledged white identity (Raby, 2004). The schools are doing their pupils a disservice if they cannot provide the education these young people need in order to live in a multi-racial society. Despite, or perhaps because of, teaching that everyone is the same and students should respect one another, racism in terms of its causes and impact, is not addressed in school. What the long term impact of this inertia will be for British society is impossible to tell.

[1] Where reference is made within this paper, to Black and Minority Ethnic people it is being used to refer to those who are not White British, not to imply that there is a 'community' of BME pupils in these schools.

[2] Including those who become 'visible' through accent/language

\section{References}

Ajegbo, K. (2007) Curriculum review: diversity and citizenship London, HMSO.

Alexander, C. (1996) The Art of Being Black. Oxford: Oxford University Press.

Benhabib, S. (1992) Situating the Self Gender, community and Postmodernism in Contemporary Ethics Cambridge: Polity Press.

Benn, S. I. \& Gaus, G. F. (1983) Public and Private in Social Life Beckenham: Croom Helm Ltd

Berman, G., \& Paradies, Y. (2010) Racism, disadvantage and multiculturalism: towards effective anti-racist praxis, Ethnic and Racial Studies, 33(2), 214- 232.

Bourdieu, P. (1977) Outline of a Theory of Practice. (R. Nice, Trans.) Cambridge: Cambridge University Press.

Byrne, B. (2005) White lives: the interplay of race, class and gender in everyday life. London: Routledge.

Cline, T., Abreu, G. d., Fihosy, C., Gray, H., Lambert, H., \& Neale, J. (2002) Minority Ethnic Pupils in Mainly White Schools. Department for Education and Skills. 
Crossley, N. (1995) Body Techniques, Agency and Intercorporeality: On Goffman's Relations in Public, Sociology, 29(1), 133 - 149.

Dyer, R. (1997) White Essays on Race and Culture. London: Routledge.

Educating Yorkshire (2013) television programme, Channel 4, UK, 5 September.

Flynn, J. E., Lensmire, T. J., \& Lewis, C. (2009) A Critical Pedagogy of Race in Teacher Education: Response and Responsibility, in S. L. Groenke, \& J. A. Hatch (Eds.), Critical Pedagogy and Teacher Education in the Neolivberal Era: Small Openings. Springer Science.

Frankenberg, R. (1993) White Women, Race Matters The Social Construction of Whiteness. Abingdon, Oxon: Routledge.

Frazer, E. \& Lacey, N. (1993) The Politics of Community A Feminist Critique of the LiberalCommunitarian Debate Hemel Hempstead: Harvester Wheatsheaf.

Gaine, C. (1987) No Problem here. Stoke-on-Trent: Trentham Books.

Gillborn, D. (1995) Racism and Anti-Racism in Schools. Buckingham: Open University Press.

Gillborn, D. (2005) Education policy as an act of white supremacy: whiteness, critical race theory and education reform Journal of Education Policy, 20(4), 485 - 505.

Gillborn, D. (2008) Racism and Education: Conspiracy or Coincidence?. Oxon: Routledge.

Goffman, E. (1961) Asylums : essays on the social situation of mental patients and other inmates. New York: Anchor Books.

Gunaratnam, Y. (2000) Researching Race and Ethnicity: Methods, Knowledge and Power. London: Sage.

Gusa, D. L. (2009) White Institutional Presence: The Impact of Whiteness on Campus Climate \& The Relational Context of White Institutional Presence. Ann Arbor: ProQuest LLC.

Hage, G. (1998) White Nation fantasies of white supremacy in a multicultural society. West Wickham, Kent: Connerford and Miller Publishers.

Hall, S. (1996) Introduction: Who needs identity? in S. H. Gay (Ed.), Questions of Cultural Identity. London: Sage Publications Ltd.

Harries, B. (2012) Talking Race in Everyday Spaces of the City Unpublished PhD thesis University of Manchester

Hartigan, J. (1997) Establishing the Fact of Whiteness. American Anthropologist, 99(3), 495 $-505$.

Hoong Sin, C. (2007) Ethnic-matching in qualitative research: reversing the gaze on 'white others' and 'white' as 'other'. Qualitative Research, 7(4), 477 - 499.

Jones, R. (1999) Teaching Racism - or Tackling it? Multicultural Stories From White Beginnning Teachers. Stoke on Trent: Trentham Books. 
Kaptani, E., \& Yuval-Davis, N. (2008) Participatory Theatre as a Research Methodology: Identity, Performance and Social Action Among Refugees. Sociological Research Online, 13 (5)(2).

Kymlicka, W. (2002) Contemporary Political Philosophy An Introduction Oxford: Oxford University Press.

Lundy, G. F. (2003) The Myths Of Oppositional Culture. Journal of Black Studies, 33(4), 450 $-467$.

Mason, J. (2002) Qualitative Researching (2nd ed.). London: Sage.

Mazzei, L. (2011) Desiring silence: gender, race and pedagogy in education British Educational Research Journal 37(4), 657-669.

Nayak, A. (1997) Tales from the darkside: negotiating whiteness in school arenas, International Studies in Sociology of Education, 7(1), 57 - 79.

Nayak, A. (1999) 'Ivory Lives' Race, Ethncity and the Practice of Whiteness Amongst Young People. PhD Thesis: University of Newcastle upon Tyne.

Noelle-Neumann, E. (1974) The spiral of silence: a theory of public opinion, Journal of Communication, 24, 43-51..

O'Leary, Z. (2004) The Essential Guide to Doing Research. London: Sage.

Pearce, S. (2012) Confronting dominant whiteness in the primary classroom: progressive student teachers' dilemmas and constraints Oxford Review of Education 38(4) 455-472.

Pearson Education Ltd. (2012) GCSE Religious Studies Specification 2012 Edexcel. http://www.edexcel.com/migrationdocuments/GCSE\%20New\%20GCSE/GCSE_Religious_Stu dies_Spec_2012.pdf

Raby, R. (2004) 'There's no racism at my school, it's just joking around:' ramifications for anti-racist education, Race, Ethnicity and Education, 7(4), 367 - 383.

Said, E. (1978) Orientalism (1st ed.). London: Routledge Keegan and Paul.

Said, E. (2000) Out of Place A Memoir. London: Granta Publications.

Sandel, M. J. (1997) The Procedural Republic and the Unencumbered Self in R. E. Goodin \& P. Pettit (ed) Contemporary Political Philosophy: An Anthology 1997 Oxford: Blackwell

Soyei, S. (n.d.) The Barriers to Challenging Racism and Promoting Race Equality in Education in England's Schools. Whitley Bay, Tyne \& Wear: Show Racism the Red Card. www.theredcard.org

Sue, C. \& Golash-Boza, T. (2013) 'It was only a joke': how racial humour fuels colour-blind ideologies in Mexico and Peru Ethnic and Racial Studies 36(10) 1582 - 1598. 
Troyna, B. (1993) Racism and Education Research Perspectives. Buckingham: Open University Press.

Troyna, B. \& Williams, J. (1986) Racism, Education and the State: The Racialisation of Education Policy. Beckenham: Croom Helm. 